\title{
Morphological and Molecular Study of Hundred-Year-Old Camellias Growing at Pazo de Lourizán, Pontevedra (NW-Spain)
}

\author{
C. Salinero, P. Vela ${ }^{*}$, A. Barros, J. L. Couselo \\ Estación Fitopatolóxica Areeiro, Deputación de Pontevedra, Spain.
}

\begin{abstract}
How to cite this paper: C. Salinero, $P$. Vela, A. Barros, J. L. Couselo. (2020) Morphological and Molecular Study of Hundred-Year-Old Camellias Growing at Pazo de Lourizán, Pontevedra (NW-Spain). International Journal of the Science of Food and Agriculture, 4(4), 502-510.

DOI: 10.26855/ijfsa.2020.12.019
\end{abstract}

Received: November 26, 2020

Accepted: December 22, 2020

Published: December 31, 2020

*Corresponding author: P. Vela, Estación Fitopatolóxica Areeiro, Deputación de Pontevedra, Spain.

Email: pilar.vela@depo.es

\begin{abstract}
Camellias have been present in Galicia for more than 250 years, and many ancient specimens are still growing in the gardens of this region. The morphology, phenology and molecular analysis (SSR markers) of 277 ancient camellia specimens growing in the historical garden of Pazo de Lourizán (Pontevedra, Spain) were studied. With the results of this study a plan of the garden was drawn, including the location of each camellia specimen. All plants except one belonged to Camellia japonica. 192 of these specimens were grouped in 35 morphological groups, of which, according to old written documents on the garden, 151 specimens were identified and ascribed to 30 cultivars. The similarity among the specimens in each group was determined by using SSR molecular markers that had been successfully used in other works to differentiate among $C$. japonica cultivars. The application of these markers, which in some cases altered the initial morphological characterization, resulted in 144 specimens identified corresponding to 30 cultivars. The 94 specimens that were not assigned to any of the morphological groups, either because they did not have distinctive morphological characteristics or did not present a single allelic profile, were included in group $\Omega$. A preliminary classification of the specimens identified in the historical garden of Pazo de Lourizán is presented in this work.
\end{abstract}

\section{Keywords}

Camellia japonica, Morphobotanic Descriptors, Molecular Markers, SSR

\section{Introduction}

The region of Galicia, in NW Spain, with rich and acid soils and a mild and humid climate, enjoys perfect conditions for camellia growth. These plants have been growing here for more than 250 years. Due to its exotic origin, the first camellias introduced in Galicia were only planted in the gardens of the Galician pazos (manor houses). However, over the years, camellia cultivation has become popular and now they can be seen growing in almost every garden, even in streets and avenues of cities and towns. Moreover, many of these ancient camellias are still present in the Galician $p a-$ zos.

Pazo de Lourizán is one of the twelve gardens included in the Route of the Camellia created by Turgalicia (Galician Tourist Board) in collaboration with the Estación Fitopatolóxica Areeiro (EFAreeiro) and the Spanish Camellia Society (SEC), with the aim to promote historical and art tourism linked to camellia culture. Located in Pontevedra (NW Spain), this 15th century manor house played an important role in political affairs in late 19th century (1879). In fact, some important decisions in the history of Spain were taken in this place. Later, in 1943, the propriety was acquired by Deputación de Pontevedra (Provincial Government) and today is the headquarters of the Forestry Research Centre of Lourizán. 
The property covers 54 hectares, comprising the gardens, the manor house and the woodland. The gardens were created in different stages during the 19th and 20th centuries, but keeping the layout of the heyday of the pazo [1]. Exotic trees and bushes were carefully arranged around the house, surrounded by boxwood beds that also border the paths and hiking trails (Figures 1 and 2). There is evidence that some of the magnolias and camellias growing around the manor house were planted between 1840 and 1850, although the camellia collection was enlarged during the 20th century. The first camellias planted during the 19th century came from the School of Agriculture in Caeira (Pontevedra) [2], from the José Marques Loureiro Nursery (Porto), Costa \& Costa Nursery (Porto) during the 19th and 20th centuries [1].

This outstanding collection of old camellia specimens is still preserved. There is also an important botanic garden (Arboretum) created in 1949 with both exotic and native species [3].
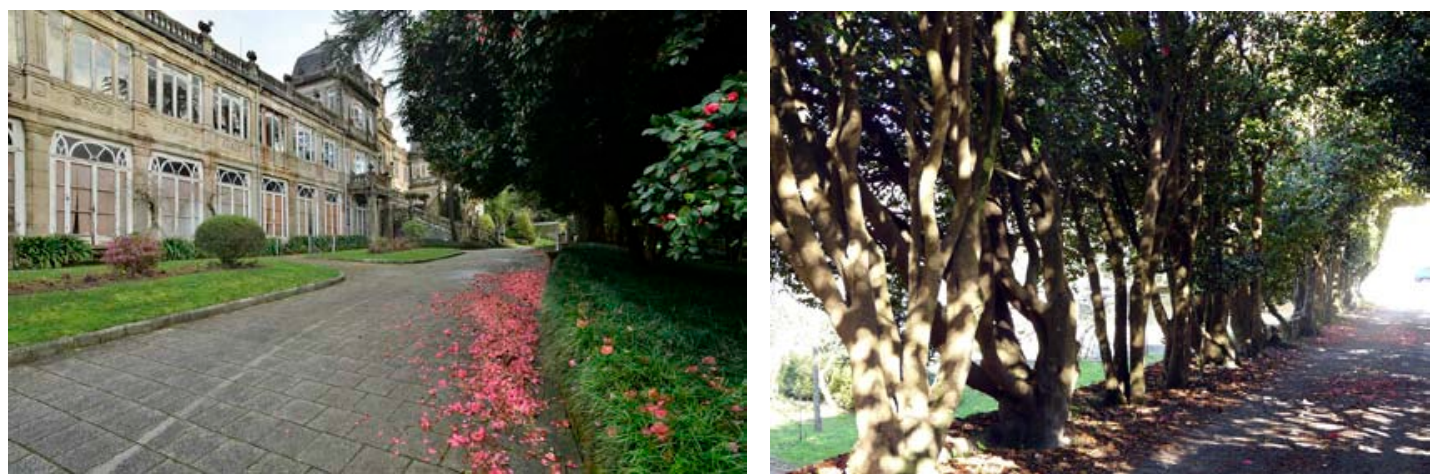

Figures 1 and 2. Front of the main building of Pazo de Lourizán and path bordered with old camellias.

Due to the botanical and historical importance that the camellias have in Galicia, in the last years several morphological studies have been carried out in Spain with the aim to characterize, differentiate and identify cultivars [4] [5] [6]. In addition, with the increasing use of molecular markers, which are combined with morphological descriptors, more reliable results have been obtained [7] [8] [9] [5].

The aim of the present work was to characterize and identify, by using morphological descriptors and microsatellite molecular markers, most specimens, especially the old ones, growing at Pazo de Lourizán.

\section{Materials and Methods}

For fourteen years plant material of 339 camellia plants growing in the garden of Pazo de Lourizán were studied. Of these plants, 227 were located in the 3-hectare part of the garden, corresponding to the oldest part. During this period, samples from camellia specimens planted in the oldest part were collected for morphological study and they were also analysed using molecular markers.

For the morphological study, 10 flowers (completely open) and 10 leaves (the second of the last year growth, from the apex to the branch) were collected from each specimen (Figures 3 and 4) and analysed according to the following 24 morphobotanic descriptors: (1) Leaves: length, width, leaf index, blade shape, apex shape, base shape, margin type; (2) Flowers: shape and size; petals (number, shape, margin type, colour, colour arrangement and venation); stamens (presence, number, arrangement, filament colour); petaloids (presence, number, variegation, arrangement); style (presence). Data on the specimen, such as growth habit, number of stems at the plant base and at a height of $1.30 \mathrm{~m}$ from the base, foliage, height, height of the canopy, basal perimeter and diameter measured at 1.30 meters from the base were analysed too. The analysis of morphological data was complemented with photographs taken from leaves and flowers and of the whole specimen. The phenological stages of the specimens were also determined, specially their blooming period.

Subsequently, the specimens were grouped according to their morphologic similarity. They were also compared to descriptions of camellia cultivars included in documents dating from the time this garden was established, such as the catalogues of the school of agriculture in A Caeira, the catalogues of the nursery of José Marques Loureiro (Porto) (from 1865 to 1887) [10] [11] [12] [13] and catalogue number 4 of the nursery of Costa \& Costa (Porto) [14]. Some invoices from the 19th century detailing the purchase of camellias (now kept in the Museum of Pontevedra) were also considered.

For the molecular analysis, young leaves in a good phytosanitary condition were collected and genomic DNA from the leaves extracted by the NucleoSpin ${ }^{\circledR}$ Plant II Kit (Macherey-Nagel), according to the standard protocol recommended by the manufacturer. $25 \mathrm{mg}$ of sample were measured and sprayed in Speed Mill Plus Homogenizer (Analytik Jena AG) and subjected to different buffers and reagents until a genomic DNA template solution was obtained. DNA was amplified with eight microsatellite markers used for C. japonica [15] [16] and C. sinensis [17] [18] (MSCjaF25; MSCjaF37; MSCjaH38; MSCjaH46; MSCjaR02; CamsinM5; CamsinM11; Z496). 

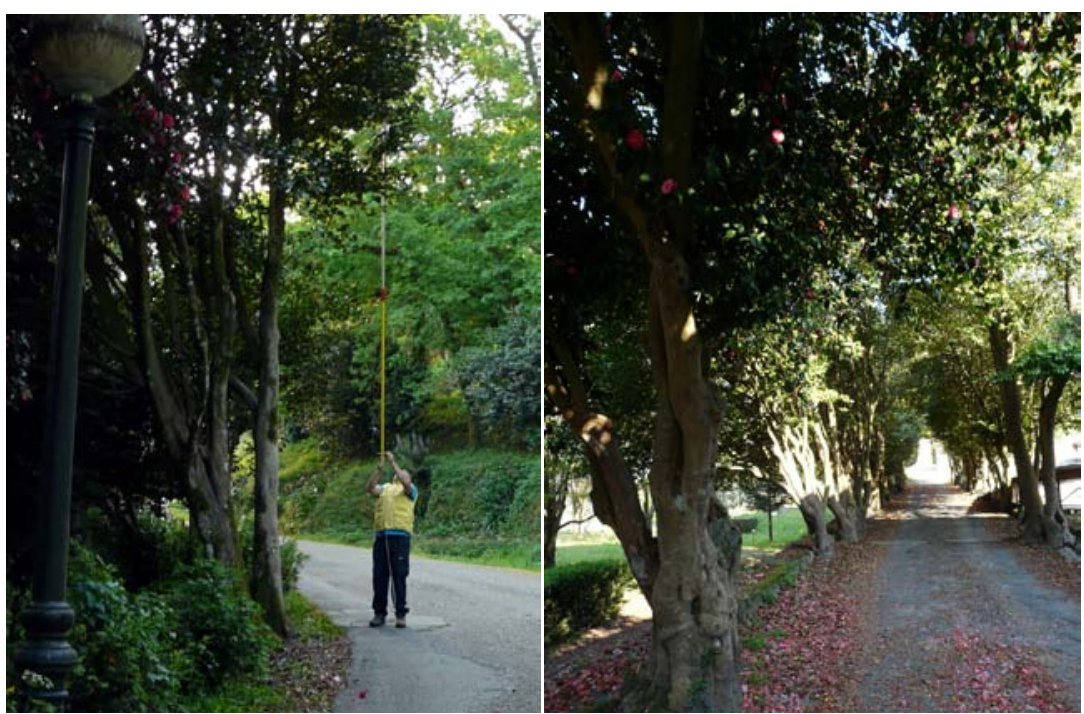

Figures 3 and 4. Collecting samples of the oldest specimens in the garden of Pazo de Lourizán.

Amplification reactions by PCR were a final volume of $25 \mu \mathrm{L}$ containing: $1 \mu \mathrm{L}$ of genomic DNA solution, $12.5 \mu \mathrm{L}$ of Kapa 2G Readymix (2X) (KappaBiosystems), $0.16 \mu \mathrm{L}$ microsatellite marker, $0.16 \mu \mathrm{L}$ fluorescent dye-labels, and $11,18 \mu \mathrm{L}$ of Milli-Q. The fluorescence dye-labels used was M13-FAM, M13-VIC, M13-PET and M13-NED. PCR reactions were performed in Termocycler Tgradient (Biometra).

Amplification conditions were: 5 minutes at $95{ }^{\circ} \mathrm{C}, 45$ cycles for 1 minute at $95{ }^{\circ} \mathrm{C}$, between 30 seconds and one minute at the corresponding hybridization temperature (TM) (Table 1), 1 minute at $72{ }^{\circ} \mathrm{C}$, and a final step of 15 minutes at $72^{\circ} \mathrm{C}$.

Amplification products were visualized on a $2 \%$ agarose (weight/volume) in a TBE $0.5 \mathrm{X}$ buffer and were viewed using a UV-transilluminator.

A volume of $1 \mu \mathrm{L}$ of amplification products was added to $15 \mu \mathrm{L}$ of formaldeide and $0.5 \mu \mathrm{L}$ Genescan-500 LIZ size standard and denatured at 95oC for 3 min. The samples were run on ABI PRISM 310 Genetic Analyser (Applied Biosystems) and analysed in Genemapper 4.0 software (Applied Biosystems).

Table 1. Characteristics of the 8 microsatellite loci of Camellia japonica and $C$. sinensis, showing the repeat motif, sequences of each primer, annealing temperature, annealing cycle time, and expected allele size

\begin{tabular}{|c|c|c|c|c|c|}
\hline $\begin{array}{l}\text { Micro } \\
\text { satellites }\end{array}$ & $\begin{array}{l}\text { Repeat } \\
\text { motif }\end{array}$ & $\begin{array}{l}\text { Primer sequences } \\
\qquad\left(5^{\prime} \rightarrow 3^{\prime}\right)\end{array}$ & $\operatorname{Tm}\left({ }^{\circ} \mathrm{C}\right)$ & $\begin{array}{l}\text { Cycle } \\
\text { time }\end{array}$ & $\begin{array}{c}\text { Size } \\
\text { expected }(\mathrm{pb})\end{array}$ \\
\hline MSCjaF25 & (CA)8(AAAAAT)4 & $\begin{array}{l}\text { F:GGGAAGGTGCATAAAATACT } \\
\text { R:TGCGACCTAAGATTACTAAA }\end{array}$ & 58 & $1 \mathrm{~min}$ & $213-245$ \\
\hline MSCjaF37 & (AG)13(GAA)7 & $\begin{array}{l}\text { F:CGCTCGACGTAATGCCACACT } \\
\text { R:CGAGCCTTCCTTTTCCCATTC }\end{array}$ & 58 & $1 \mathrm{~min}$ & $344-370$ \\
\hline MSCjaH38 & (GA)14 & $\begin{array}{l}\text { F:CCTATTGCCTACGACCATTTC } \\
\text { R:GCTGAGCTTGGAGATTTTGTT }\end{array}$ & 55 & $1 \mathrm{~min}$ & $343-362$ \\
\hline MSCjaH46 & (GA)16 & $\begin{array}{l}\text { F:AGGGAGCATTATGAGTCGTCT } \\
\text { R:CATCGTCCTAATCCACTTCAC }\end{array}$ & 58 & $1 \mathrm{~min}$ & $443-461$ \\
\hline MSCjaR02 & (CT)8...(CT)11 & $\begin{array}{l}\text { F:AAGGGTGATGCAAAAGTGAGA } \\
\text { R: TTCTTTGGGTTGTGTTCCAA }\end{array}$ & 55 & $1 \mathrm{~min}$ & $219-248$ \\
\hline CamsinM5 & (GT)15(GA)8 & $\begin{array}{l}\text { F:AAACTTCAACAACCAGCTCTGGTA } \\
\text { R:AATTATAGGATGCAAACAGGCATGA }\end{array}$ & 55 & $1 \mathrm{~min}$ & $206-224$ \\
\hline CamsinM11 & (CA)12 & $\begin{array}{l}\text { F:GCATCATTCCACCACTCACC } \\
\text { R:GTCATCAAACCAGTGGCTCA }\end{array}$ & 55 & $1 \mathrm{~min}$ & $173-182$ \\
\hline Z496 & $(A G) 11$ & $\begin{array}{l}\text { F:GAAAGTGCGAAACCAAAC } \\
\text { R:CTGCGAACCCTCTTGACC }\end{array}$ & 55 & $1 \mathrm{~min}$ & $102-122$ \\
\hline
\end{tabular}




\section{Results}

The old part of the garden of Pazo de Lourizán has 277 camellia plants, of which more than 200 specimens were planted before 1950. These specimens were found and marked on the map (Figure 5).

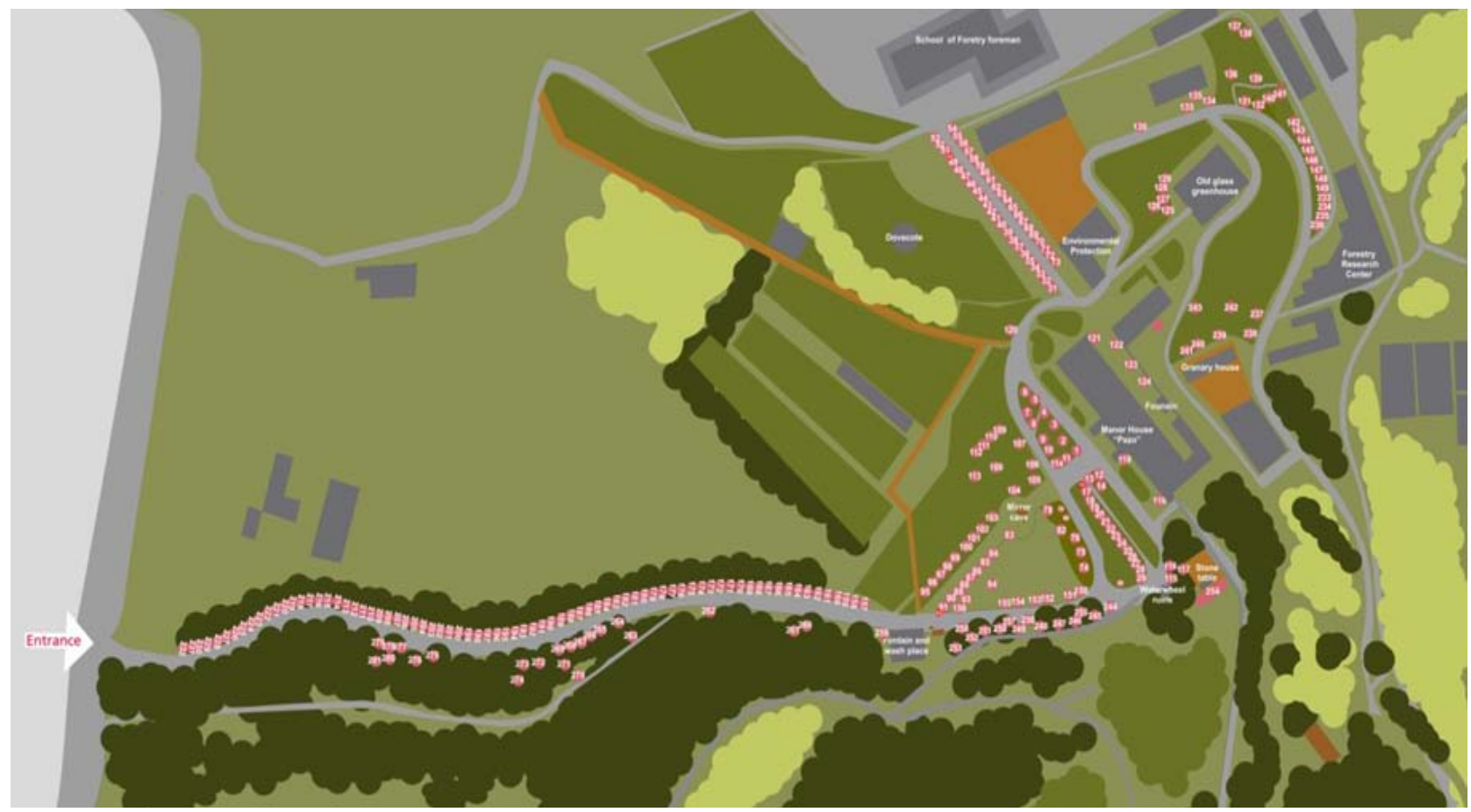

Figure 5. Plan of the old part of the garden showing the camellia location.

Of them, 192 specimens were grouped according to their morphological characteristics in 35 morphological groups, of which 151 were ascribed to 30 cultivars and the other 41 were included in 5 unnamed groups, since they were not similar to any known cultivar (Table 2). 85 specimens that were not assigned to any of the morphological groups, either because they did not have distinctive morphological characteristics or did not present a single allelic profile, were included in group $\Omega$. The results of the morphological and molecular analysis were as follows:

1. Group A: it includes 5 specimens (5, 85, 102, 128 and 150) morphologically grouped and identified as 'Incarnata' (Escuela de Agricultura de Pontevedra, 1882 [19]; Costa \& Costa, 1889 [14]). This cultivar was known in Galicia with the name 'Carnea'. That was the name also given by the nursery of this pazo, which until 2000 sold plants propagated in the nursery from material taken from old plants growing in the garden. In catalogue number 4 (1889) of the nursery of Costa \& Costa (Porto) [14], on page 18, the cultivar 'Carnea' includes a description that corresponded to 'Incarnata'.

2. Group B: identified as 'Alba Plena'. 23 specimens (87, 88, 94, 97, 98, 99, 100, 103, 104, 107, 109, 132, 137, 138, $151,153,158,166,177,178,223,227$ and 237) were ascribed to this cultivar because they presented similar morphobotanic characteristics. All the specimens were confirmed by molecular analysis except 109 and 223, which were included in group $\Omega$.

3. Group C: identified as 'Antonio Bernardo Ferreira'. According to its morphobotanic description, 13 camellias were included in this group (32, 33, 44, 66, 152, 163, 164, 185, 195, 198, 214, 220 and 232), which were also analyzed by molecular markers, thus confirming the results of the morphological analysis. Specimens 25 and 28 , initially ascribed to $\Omega$, were also included in this group.

4.Group D: including 16 specimens (47, 65, 130, 154, 155, 156, 160, 162, 174, 175, 182, 183, 188, 210, 218 and 228) identified as 'Dom Pedro V, Rei de Portugal', given their morphobotanic features. According to the molecular analysis, there were three different groups, which must be compared with the assigned cultivar in further studies.

5. Group E: identified as 'Doutor Balthazar de Mello’ includes 13 camellia plants (43, 157, 170, 176, 184, 186, 189, 190, 196, 200, 201, 207 and 212) using morphological descriptors. The similarity among specimens was confirmed using molecular markers.

6. Group F: 33 specimens with single flowers were included in this group (20, 22, 38, 48, 49, 51, 52, 56, 57, 59, 60, 62, 63, 64, 70, 72, 74, 77, 81, 113, 159, 165, 167, 168, 173, 179, 180, 181, 187, 206, 209, 222 and 271). These results need to be confirmed by molecular techniques.

7. Group G: with 3 camellia specimens (69, 171 and 226) with white single flowers that need to be subsequently 
analyzed by molecular techniques.

8. Group H: 9 specimens were grouped using morphobotanic descriptors (2, 3, 34, 36, 40, 172, 193, 219 and 229) that were identified as 'Peonia Rubra Portuensis' [10] [11] [19]. By molecular analysis, it was confirmed that 9 specimens showed identical allelic profiles with the 8 markers. The specimen 31, previously included in group $\mathrm{S}$ after performing the morphological analysis, was also incorporated to this group because it had an allelic profile similar to these 9 specimens.

9. Group IA: 6 plants were included $(17,24,37,54,58$ and 192) according to their morphological features. After the molecular analysis, 5 of them shared the same allelic profile [6]. The specimens 27 and 73, initially included in Group Y were also incorporated. Specimen 192 was incorporated to group $\Omega$, since it presented a distinctive allelic profile.

10. Group IB: identified as 'Pomponia Alba Monstruosa' [10] [11] [12] [13] [19], it includes specimens 21, 35 and 55. Molecular analysis confirmed that the 3 specimens belong to the same group.

11. Group IC: 6 camellia specimens were included in this group (12, 13, 23, 110, 129 and 208) which were morphologically ascribed to 'Conde da Torre' [10] [12] [13] [19]. The identification of specimens 12, 110, 129 and 208 was confirmed after the molecular analysis. The other two specimens were ascribed to group $\Omega$.

12. Group J: identified as 'Bella Romana', it includes 8 specimens (78, 84, 90, 95, 127, 131, 217, 221) with similar morphological characteristics [10]. Molecular techniques confirmed the identification of all cultivars except 90, which was included in group $\Omega$.

13. Group K: specimen 203 was morphologically similar to 'Bento de Amorim'. The identification must be confirmed by molecular analysis by comparing it with a reference cultivar.

14. Group L: using the morphobotanic descriptors 10 specimens were included (4, 7, 61, 83, 106, 108, 194, 205, 215 and 230) identified as 'Duqueza de Palmella' [10] [11] [12] [19]. Molecular analysis showed that 3 allelic profiles were present in this group: one corresponded to 'Duqueza de Palmella' (specimens 4, 61, 83, 106, 108, 194 and 215); specimens 7 and 230 were included in group $\beta$ since they presented the allelic profile of this group; and specimen 205 was incorporated to group $\Omega$.

15. Group M: including a single specimen (231), identified by morphology as 'Emilia' [10] [19]; it presented an allelic profile different from all the rest of the specimens analyzed by molecular techniques.

16. Group N: using the morphobotanic descriptors, the camellia specimens 71 and 93 were included in this group and identified as 'Dom Fernando II de Portugal' [10] [11] [12] [13] [19].

17. Group O: 3 specimens were included $(6,105$ and 111) in this group because they were morphologically similar and identified as 'Marqueza da Fronteira' [10] [11] [12] [13] [19]. The molecular analysis confirmed the identification of specimens 6 and 105, as well as the specimen 242, previously included in group $\Omega$ after the morphobotanic charact erization. However, specimen 111 was included in group $\Omega$ since it showed an allelic profile different from the rest of the specimens in the group.

18. Group P: specimen 46 was morphologically different from the rest and was identified as 'Sweetiana' [10] [19].

19. Group Q: specimen 199 was identified by morphology and SSR markers as 'Imperatriz Amelia' [10] [11] [12] [13].

20. Group R: specimens 86, 91 and 134 were identified as 'Cidade de Vigo'. All of them were planted recently.

21. Group S: Specimens 29 and 31 were initially ascribed to this group and identified as 'Marmorea Portuensis' [10] [11]. After performing the molecular analysis, specimen 31 showed an allelic profile identical to the one corresponding to group $\mathrm{H}$, thus it was finally included in this group.

22. Group T: comprises a young plant (8) with morphobotanic and molecular features different from those previously studied, especially as regards the characteristics of the leaf.

23. Group U: includes two specimens (9 and 11) with formal double, deep pink coral flowers, showing similar morphological and molecular characteristics but different from the rest of specimens studied. A name was not given yet.

24. Group V: the specimen 112 was identified morphologically and by molecular analysis as 'Centifolia Rosea' [14] [19].

25. Group W: it comprises a single young plant, identified as 'Chandleri'.

26. Group X: of the 9 plants initially included in this group, and identified as 'Corallina' [10], four of them (41, 42, 45 and 211) showed a similar allelic profile. The rest (53, 197, 204, 224 and 225) had distinctive and different allelic profiles, thus they were included in group $\Omega$.

27. Group Y: it initially comprised plants 27 and 73, which shared an allelic profile identical to the specimens of Group IA, thus group Y disappeared.

28. Group Z: specimens 139, 191 and hedge 254, corresponded to 'Dona Herzilia de Freitas Magalhaes'. Specimens 139, 191 and hedge 254, corresponded to 'Dona Herzilia de Freitas Magalhaes'. After performing the molecular analysis, specimens 144 and 147 showed allelic profile identical to the one corresponding to this group thus it was finally included in this group.

29. Group $\alpha$ : specimen 241 belongs to 'Virginia Franco'. 
30. Group $\beta$ : the specimen 161 was identified as 'Camille Brozzoni'; after the molecular analysis plants 7 and 230 (initially ascribed to group L) showed that they also belonged to this group.

31. Group $\delta$ : specimens 136, 235 and 236 belong to cultivar 'Angelina Vieira'.

32. Group $\varepsilon$ : specimens 133 and 149 were identified as 'Herzilia II'.

33. Group $\pi$ : the specimen 234 corresponded to 'Jury's Yellow'.

34. Group $\chi$ : specimen 240 belongs to 'Eugenia de Montijo'.

35. Group $\phi$ : specimens 121 and 126 belong to 'Sangre de Pichón'. They showed an identical allelic profile.

36 . Group $\Omega$ : it comprises all the specimens that were not included in any of the previous groups, either because they did not have distinctive morphological characteristics or did not present a single allelic profile.

Of the 35 groups initially created on the basis of the established morphobotanic descriptors, groups F, G, K, P, Q, R, $\mathrm{T}, \mathrm{W}$, and $\alpha$ were not subjected to molecular analysis, thus either new groups may appear or the existing ones may be altered.

In groups $\mathrm{A}, \mathrm{E}, \mathrm{IB}, \mathrm{M}, \mathrm{N}, \mathrm{R}, \mathrm{U}, \varepsilon, \delta, \pi, \chi$ and $\phi$, the molecular analysis confirmed the identification performed using morphobotanic descriptors. The other groups were modified according to the results obtained after performing the molecular analysis (B, C, D, H, IA, IC, J, L, O, S, X, Y, Z and $\beta$ ).

After the molecular analysis, the group $\Omega$ included 94 unidentified specimens, which presented different allelic profiles.

\section{Discussion}

The identification of Camellia species and cultivars is mainly based on the morphological features of flowers and leaves and, to a lesser extent, on the type of plant growth. However, all these features can be affected by ontogenetic and environmental factors [20] [21]. Some morphological characteristics, especially those of flowers, are highly variable among specimens belonging to the same cultivar and even among flowers of the same plant, which makes the visual and subjective evaluation of the researcher very difficult [9]. Furthermore, these descriptors can be influenced by specific factors related to the specimen development and to environmental factors, which can mask true genetic diversity [20] [22].

New camellia cultivars, those originated in the last 50 years, are well documented with photographs and information about their morphological characteristics, thus their identification is supposed to be relatively easy. However, identification of old cultivars is more complex due to the lack of documentation about them and only relies on some drawings and descriptions of their morphological features included in catalogues and manuscripts of old books, which is insufficient and often confusing [23] [9] [24] [25].

For the characterization and identification of camellia cultivars, as for other wild and cultivated plant species, morphobotanic description is complemented with molecular techniques (SSR), which have proven to be very useful [7] [9] [5] [26]. In order to confirm the identification of a cultivar, it is necessary to have a reference specimen for that cultivar [7] [5] [24].

In this work, the application of morphobotanic descriptors allowed the identification of 151 specimens of the 277 growing in the old part of the garden of Pazo de Lourizán. However, after the molecular characterization using SSR markers, it was proven that only 142 corresponded to the cultivar to which they had been initially ascribed. In other words, after the molecular analysis, more than $93 \%$ of the specimens that had been previously grouped by their morphology were confirmed.

It was found that the morphological characterisation was not enough, and 17 specimens (8.9\%) did not really belong to the cultivar to which they had been initially ascribed according to its morphology. This is the case of some specimens which were identified as 'Alba Plena', 'Pompone', 'Conde da Torre' or 'Bella Romana' cultivars, among others, which after the molecular characterization were included in group $\Omega$ (unidentified specimens).

The lack of reference specimens for some cultivars made their identification impossible although it was possible to group them according to their morphology. Thus, only 54.5\% of the specimens could be correctly identified.

\section{Conclusion}

Due to the great diversity of shapes and colours of camellia cultivars, it makes it difficult to perform an accurate and correct identification of them. By means of morphological characterization, using 24 selected characters, identification is possible in a relatively high number of cultivars. However, identification is even more difficult when cultivars are over 100 years old and there is lack of information on their morphology in existing documents. The only way to identify a cultivar correctly is by using molecular techniques as a complement to morphobotanic characterization.

Thus, for the characterization and identification of ancient camellia cultivars it is necessary to keep a collection of reference cultivars, which should be universal and accessible to all countries. This is the only way to perform a correct identification of the ancient camellia specimens that have been growing in our gardens for more than 100 years. 
Table 2. 277 C. japonica specimens growing in the old garden of Lourizán assigned to different groups according to their morphological and molecular features

\begin{tabular}{|c|c|c|c|c|c|c|c|}
\hline Group & Flower description & Type cultivar & Morphological group & $\begin{array}{l}\text { Total } \\
\text { plants }\end{array}$ & Molecular biology group & $\begin{array}{l}\text { Total } \\
\text { plants }\end{array}$ & Photo \\
\hline $\mathbf{A}$ & $\begin{array}{l}\text { Formal double; } \\
\text { cream white, pale pink } \\
\text { external petals }\end{array}$ & Incarnata & $5 ; 85 ; 102 ; 128 ; 150$ & 5 & $5 ; 85 ; 102 ; 128 ; 150$ & 5 & \\
\hline B & Formal double; white & Alba Plena & $\begin{array}{c}\text { 87; 88; 94; 97; 98; 99;100; } \\
\text { 103; 104; } 107 ; 109 ; 132 ; 137 ; \\
138 ; 151 ; 153 ; 158 ; 166 ; 177 ; \\
178 ; 223 ; 227 ; 237\end{array}$ & 23 & \begin{tabular}{|c|} 
87; 88; 94; 97; 98; 99;100; \\
103; 104; 107; 132; 137; $138 ;$ \\
$151 ; 153 ; 158 ; 166 ; 177 ; 178 ;$ \\
$227 ; 237$
\end{tabular} & 21 & \\
\hline C & $\begin{array}{c}\text { Formal double; outer petals } \\
\text { dark pink and inner petals } \\
\text { light pink }\end{array}$ & Antonio Bernardo Ferreira & $\begin{array}{l}32 ; 33 ; 44 ; 66 ; 152 ; 163 ; 164 ; \\
185 ; 195 ; 198 ; 214 ; 220 ; 232\end{array}$ & 13 & $\begin{array}{c}25 ; 28 ; 32 ; 33 ; 44 ; 66 ; 152 ; \\
163 ; 164 ; 185 ; 195 ; 198 ; 214 ; \\
220 ; 232\end{array}$ & 15 & \\
\hline D & $\begin{array}{c}\text { Formal double / rose form; } \\
\text { white slightly } \\
\text { streaked in light pink }\end{array}$ & $\begin{array}{l}\text { Dom Pedro V, } \\
\text { Rei de Portugal }\end{array}$ & $\begin{array}{r}47 ; 65 ; 130 ; 154 ; 155 ; 156 ; \\
160 ; 162 ; 174 ; 175 ; 182 ; 183 \\
\quad 188 ; 210 ; 218 ; 228\end{array}$ & 16 & & 16 & \\
\hline $\mathbf{E}$ & $\begin{array}{l}\text { Rose form; } \\
\text { pink or white } \\
\text { streaked in pink }\end{array}$ & $\begin{array}{c}\text { Bonomiana } \\
\text { Doutor Balthazar de Mello }\end{array}$ & $\begin{array}{r}43 ; 157 ; 170 ; 176 ; 184 ; 186 ; \\
189 ; 190 ; 196 ; 200 ; 201 ; 207 ; \\
212\end{array}$ & 13 & $\begin{array}{c}43 ; 157 ; 170 ; 176 ; 184 ; 186 ; \\
189 ; 190 ; 196 ; 200 ; 201 ; 207 ; \\
212\end{array}$ & 13 & \\
\hline $\mathbf{F}$ & Single; carmine & - & $\begin{array}{c}20 ; 22 ; 38 ; 48 ; 49 ; 51 ; 52 ; 56 ; \\
57 ; 59 ; ; 0 ; 62 ; 63 ; 64 ; 70 ; 72 ; \\
74 ; 77 ; 81 ; 113 ; 159 ; 165 ; 167 ; \\
168 ; 173 ; 179 ; 180 ; 181 ; 187 \\
206 ; 209 ; 222 ; 271\end{array}$ & 33 & & 33 & \\
\hline G & Single; white & - & $69 ; 171 ; 226$ & 3 & & 3 & \\
\hline $\mathbf{H}$ & Anemone; pink & Peonia Rubra Portuensis & $\begin{array}{c}2 ; 3 ; 34 ; 36 ; 40 ; 172 ; 193 ; \\
219 ; 229\end{array}$ & 9 & $\begin{array}{c}2 ; 3 ; 31 ; 34 ; 36 ; 40 ; 172 ; 193 ; \\
219 ; 229\end{array}$ & 10 & \\
\hline IA & $\begin{array}{c}\text { Anemone; white streaked in } \\
\text { pink / white / pink }\end{array}$ & Pompone & $17 ; 24 ; 37 ; 54 ; 58 ; 192$ & 6 & $17 ; 24 ; 27 ; 37 ; 54 ; 58 ; 73$ & 7 & \\
\hline IB & $\begin{array}{c}\text { Anemone; white streaked in } \\
\text { pink / white }\end{array}$ & Pomponia Alba Monstruosa & $21 ; 35 ; 55$ & 3 & $21 ; 35 ; 55$ & 3 & \\
\hline IC & Anemone; white & Conde da Torre & $12 ; 13 ; 23 ; 110 ; 129 ; 208$ & 6 & 12; 110; 129; 208 & 4 & \\
\hline $\mathbf{J}$ & $\begin{array}{c}\text { Imbricated / peony; } \\
\text { white or pink streaked in } \\
\text { crimson }\end{array}$ & Bella Romana & $\begin{array}{c}78 ; 84 ; 90 ; 95 ; 127 ; 131 ; 217 \\
221\end{array}$ & 8 & $78 ; 84 ; 95 ; 127 ; 131 ; 217 ; 221$ & 7 & \\
\hline $\begin{array}{l}\mathbf{K} \\
*\end{array}$ & Semidouble; red & Bento de Amorim & 203 & 1 & 203 & 1 & \\
\hline $\mathbf{L}$ & $\begin{array}{l}\text { Formal double; pink, } \\
\text { streaked in white }\end{array}$ & Duquesa de Palmella & $\begin{array}{c}4 ; 7 ; 61 ; 83 ; 106 ; 108 ; 194 ; \\
205 ; 215 ; 230\end{array}$ & 10 & $4 ; 61 ; 83 ; 106 ; 108 ; 194 ; 215$ & 7 & \\
\hline M & $\begin{array}{l}\text { Anemone/peony; pink with } \\
\text { white center }\end{array}$ & Emilia & 231 & 1 & 231 & 1 & \\
\hline $\mathbf{N}$ & $\begin{array}{l}\text { Anemone; light pink, } \\
\text { variegated }\end{array}$ & $\begin{array}{c}\text { Dom Fernando II de } \\
\text { Portugal }\end{array}$ & $71 ; 93$ & 2 & $71 ; 93$ & 2 & \\
\hline $\mathbf{O}$ & Rose form; red & Marqueza da Fronteira & $6 ; 105 ; 111 ;$ & 3 & $6 ; 105 ; 242$ & 3 & \\
\hline $\mathbf{P}$ & $\begin{array}{c}\text { Rose form; pink variegated } \\
\text { in white }\end{array}$ & Swetiana & 46 & 1 & 46 & 1 & \\
\hline
\end{tabular}




\begin{tabular}{|c|c|c|c|c|c|c|c|}
\hline Group & Flower description & Type cultivar & Morphological group & $\begin{array}{l}\text { Total } \\
\text { plants }\end{array}$ & Molecular biology group & $\begin{array}{l}\text { Total } \\
\text { plants }\end{array}$ & Photo \\
\hline $\mathbf{Q}$ & $\begin{array}{l}\text { Peony; light pink striped } \\
\text { carmine, petals bordered } \\
\text { with white }\end{array}$ & Imperatriz Amelia & 199 & 1 & 199 & 1 & \\
\hline $\begin{array}{l}\mathbf{R} \\
*\end{array}$ & $\begin{array}{l}\text { Peony; white variegated in } \\
\text { pink }\end{array}$ & Cidade de Vigo & $86 ; 91 ; 134$ & 3 & $86 ; 91 ; 134$ & 3 & \\
\hline $\mathbf{S}$ & Anemone & Marmorea Portuensis & $29 ; 31$ & 2 & 29 & 1 & \\
\hline $\begin{array}{l}\mathbf{T} \\
*\end{array}$ & $\begin{array}{l}\text { Rose form/peony; } \\
\text { dark pink }\end{array}$ & - & 8 & 1 & & 1 & \\
\hline $\mathbf{U}$ & Formal double; coral pink & - & $9 ; 11$ & 2 & $9 ; 11$ & 2 & \\
\hline $\mathbf{V}$ & $\begin{array}{l}\text { Formal double / rose form; } \\
\text { red streaked in white }\end{array}$ & Centifolia Rosea & 112 & 1 & 112 & 1 & \\
\hline $\begin{array}{l}\text { W } \\
*\end{array}$ & $\begin{array}{l}\text { Rose form; red, streaked } \\
\text { and spotted in white }\end{array}$ & Chandleri & 89 & 1 & 89 & 1 & \\
\hline $\mathbf{X}$ & Anemone; carmine & Corallina & $\begin{array}{c}41 ; 42 ; 45 ; 53 ; 197 ; 204 ; 211 ; \\
224 ; 225\end{array}$ & 9 & $41 ; 42 ; 45 ; 211$ & 4 & \\
\hline $\mathbf{Y}$ & Anemone; light pink & & $27 ; 73$ & 2 & & 0 & \\
\hline $\begin{array}{l}\mathrm{Z} \\
*\end{array}$ & Anemone/peony & $\begin{array}{c}\text { Dona Herzilia de Freitas } \\
\text { Magahanães }\end{array}$ & 139; 191; 254 (hedge) & 3 & 139; 144; 147; 254 (hedge) & 4 & \\
\hline$\alpha$ & Formal double, light pink & Virginia Franco & 241 & 1 & 241 & 1 & \\
\hline$\beta$ & Formal double; pink & 'Camille Brozzoni' & 161 & 1 & $161 ; 7 ; 230$ & 3 & \\
\hline $\begin{array}{l}\delta \\
*\end{array}$ & Formal double; blush rose & Angelina Vieira & $136 ; 235 ; 236$ & 3 & $136 ; 235 ; 236$ & 3 & \\
\hline $\begin{array}{l}\varepsilon \\
*\end{array}$ & Anemone / peony & Herzilia II & $133 ; 149$ & 2 & $133 ; 149$ & 2 & \\
\hline $\begin{array}{l}\pi \\
*\end{array}$ & Anemone; light yellow & Jury's Yellow & 234 & 1 & 234 & 1 & \\
\hline $\begin{array}{l}\text { c } \\
*\end{array}$ & Formal duble; red & Eugenia de Montijo & 240 & 1 & 240 & 1 & \\
\hline $\begin{array}{l}\mathbf{f} \\
*\end{array}$ & Anemone; very dark red & Sangre de Pichón & $121 ; 126$ & 2 & $121 ; 126$ & 2 & \\
\hline $\boldsymbol{\Omega}$ & Several & & 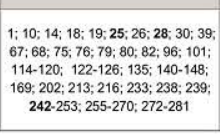 & 85 & 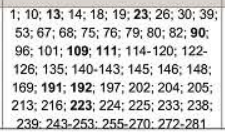 & 94 & \\
\hline
\end{tabular}




\section{References}

[1] Salinero, C., Toval, G., González, M., Neves, A. (2011). El Pazo de Lourizán. Camelia, 19: 14-23.

[2] Barbazán, A., González, M., Salinero, C., Valle, J. C. (2009). La camelia en los catálogos de los establecimientos de Agricultura de La Caeira (1873-1886) de Pontevedra. Camellia, 14: 13-22.

[3] Silva-Pando F. J. (2001). Catálogo florístico vascular del Jardín Botánico de Lourizán. Xunta de Galicia, Santiago de Compostela.

[4] Salinero, C., Vela, P. (2004). La camelia en la Colección de la Diputación de Pontevedra. Diputación de Pontevedra, Pontevedra.

[5] Vela, P., Salinero, C., Couselo, J. L., Paz, C., González-García, M., Sainz, M. J. (2013). Characterization of Camellia japonica cultivars using molecular markers. International Camellia Journal, 45: 61-70.

[6] Vela, P., Couselo, J. L., Salinero, C., Paz, C. (2014). Differentiation of camellia specimens with morphological similarities using morphobotanic descriptors and SSR. International Camellia Journal, 46: 55-56.

[7] Caser, M., Torello Marinini, D., Scariot V. (2010). Microsatellite-based genetic relationships in the genus Camellia: potential for improving cultivars. Genome, 53(5): 384-399.

[8] Couselo, J. L., Vela, P., Salinero, C., Sainz, M. J. (2010). Characterization and differentiation of old Camellia japonica cultivars using single sequence repeat (SSRs) as genetic markers. International Camellia Journal, 42: 117-122.

[9] Vela, P. (2011). Caracterización y diferenciación de cultivares de Camellia japonica mediante descriptores morfobotánicos y marcadores moleculares. In: Fenología y caracterización morfológica y molecular de cultivares de Camellia japonica en Galicia. Ph.D. Thesis, Universidad de Santiago de Compostela, Santiago de Compostela.

[10] Savige, T. J. (1993). The International Camellia Register. Ed. The International Camellia Society, Wirlinga, NSW, Australia.

[11] Marques Loureiro, J. (1868). Catalogo do Estabelecimento de Horticultura de José Marques Loureiro $\mathrm{n}^{\circ} 5$. Typographia do jornal do Porto, Porto.

[12] Marques Loureiro, J. (1882). Catalogo Geral e Descriptivo das plantas cultivadas do Real Estabelecimento Horticola de José marques Loureiro $\mathrm{n}^{\circ}$ 19. Typographia Occidental, Porto.

[13] Marques Loureiro, J. (1887). Catalogo Geral e Descriptivo das plantas cultivadas do Real Estabelecimento Horticola de José marques Loureiro $\mathrm{n}^{\circ}$ 22. Typ. De A.F. Vasconcellos, Porto.

[14] Monteiro da Costa, J. (1889). Catalogo Estabelecimento de horticultura Costa \& Costa $\mathrm{n}^{\circ} 4$. Imprenta Internacional, Porto.

[15] Ueno, S., Yoshimaru, H., Tomaru, N., Yamamoto, S. (1999). Development and characterization of microsatellite markers in Camellia japonica L. Molecular Ecology, 8: 335-346.

[16] Abe, H., Matsuki, R., Ueno, S., Nashimoto, M., Hasegawa, M. (2006). Dispersal of Camellia japonica seeds by Apodemus speciosus revealed by maternity analysis of plants and behavioral observation of animal vectors. Ecological Research, 21: $732-740$

[17] Freeman, S., West, J., James, C., Lea, V., Mayess, S. (2004). Isolation and characterization of highly polymorphic microsatellites in tea (Camellia sinensis). Molecular Ecology Notes, 4: 324-326.

[18] Zhao, L. P., Liu, Z., Chen, E. L., Yao, E. M. Z., Wang, E. X. C. (2008). Generation and characterization of 24 novel EST derived microsatellites from tea plant (Camellia sinensis) and cross-species amplification in its closely related species and varieties. Conservation Genetics, 9: 1327-1331.

[19] Escuela de Agricultura de Pontevedra. (1882). Catálogo de los árboles, arbustos, plantas, bulbos y semillas. Sus precios. Imp. de Rogelio Quintans, Pontevedra.

[20] Banerjee, B. (1992). Selection and breeding of tea. In: Tea: cultivation to consumption. Eds. K.C. Wilson y M.N. Clifford. Chapman and Hall, London, 53-85.

[21] Zhao, Y., Ruan, C. J., Ding, G. J, Mopper, S. (2017). Genetic relationships in a germplasm collection of Camellia japonica and Camellia oleifera using SSR analysis. Genetica and Molecular Researche, 16(1). DOI: 10.4238/gmr16019526.

[22] Trehane, J. (2007). Camellias: the gardener's encyclopedia. Timber Press, Inc. Portland, Oregon.

[23] Corneo, A., Remotti, D. (2003). Camelie dell'Ottocento nel Verbano. Regione Piemonte, Torino.

[24] Vela, P., Salinero, C., Sainz, M. J., González, M., Couselo, J. L. (2011). Establishment of a field germplasm bank of Camellia reference cultivars. International Camellia Journal, 43: 30-35.

[25] Soignon, J., Mahuas, R. (2018). 1001 camellias à Nantes et dans toute la Bretagne. Eds. D’Orbestier. Saint-Sébastien-sur-Loire.

[26] Yadav, M. K., Aravindan, S., Ngangkham, U., Shubudhi, H. N., Bag, M. K., Adak, M., Munda, S., Samantaray, S., Jena, M. (2017). Use of molecular markers in identification and characterization of resistance to rice blast in India. PLoS One, 2017, 12(4): e0176236. DOI: 10.1371/journal.pone.0176236. 